\title{
Rare cause of acute angle-closure glaucoma in an elderly man
}

\author{
Teena Mariet Mendonca, ${ }^{\oplus 1}$ Suja Sreedharan, ${ }^{2}$ Gladys Reshma Rodrigues, ${ }^{1}$ \\ Mounika Vala ${ }^{1}$
}

\begin{abstract}
${ }^{1}$ Department of Ophthalmology, Kasturba Medical College Mangalore, Manipal Academy of Higher Education, Manipal, Karnataka, India

${ }^{2}$ Department of Otorhinolaryngology, Kasturba Medical College Mangalore, Manipal Academy of Higher Education, Manipal, Karnataka, India
\end{abstract}

\section{Correspondence to}

Dr Gladys Reshma Rodrigues, glads023@gmail.com

Accepted 21 May 2019

\section{DESCRIPTION}

A 62-year-old man presented to the ophthalmology department with acute onset of pain, redness and diminution of vision in the right eye since 2 days. $\mathrm{He}$ was diagnosed to have craniofacial fibrous dysplasia, 5 years ago, which was confirmed with the biopsy. He gave history of gradually progressive outward deviation of right eye since 5 years for which he did not seek any treatment. On examination, his visual acuity was 20/200 in right eye and 20/20 in left eye. Examination of extraocular motility revealed outward and downward displacement of the right eye with total limitation of adduction and elevation. However, there was no proptosis of the right eye. Anterior segment examination revealed ciliary congestion of the right eye with mild chemosis and dilated episcleral veins (figure 1). Slit lamp examination revealed shallow anterior chamber with mid-dilated, fixed pupil and dense nuclear sclerosis of the lens. Fundus examination revealed normal appearance of optic disc with dilated and tortuous retinal veins. Gonioscopy revealed closed angles in all four quadrants. Intaocular pressure by Goldman applanation tonometry was $60 \mathrm{~mm} \mathrm{Hg}$. Left eye examination was unremarkable except for minimal senile cataract. Gonioscopy of the left eye revealed open angles in all quadrants. He was treated with pilocarpine eye drops, oral acetazolamide $500 \mathrm{mg}$ and topical antiglaucoma medicines, which reduced the intraocular pressure to $26 \mathrm{~mm} \mathrm{Hg}$. CT of the orbits and brain was performed, which revealed extensive soft tissue opacification of bilateral frontal sinuses with blockage of fronto-ethmoidal recess and defect in floor of bilateral frontal sinuses. Soft tissue density

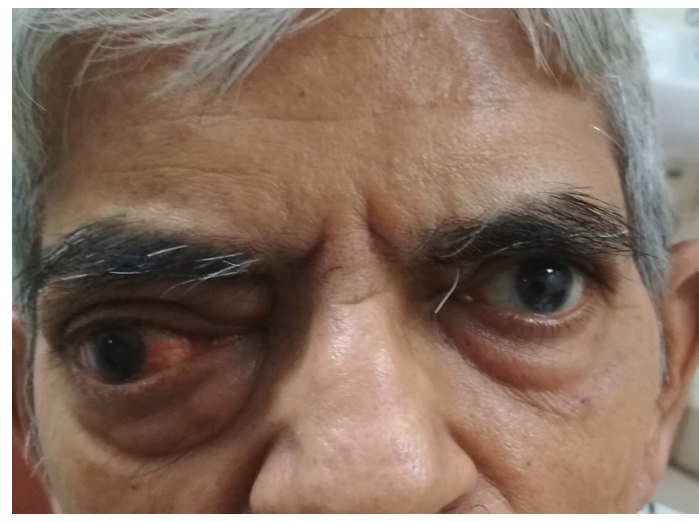

Figure 1 Clinical photograph of the patient showing conjunctival congestion with outward and downward displacement of right eye.

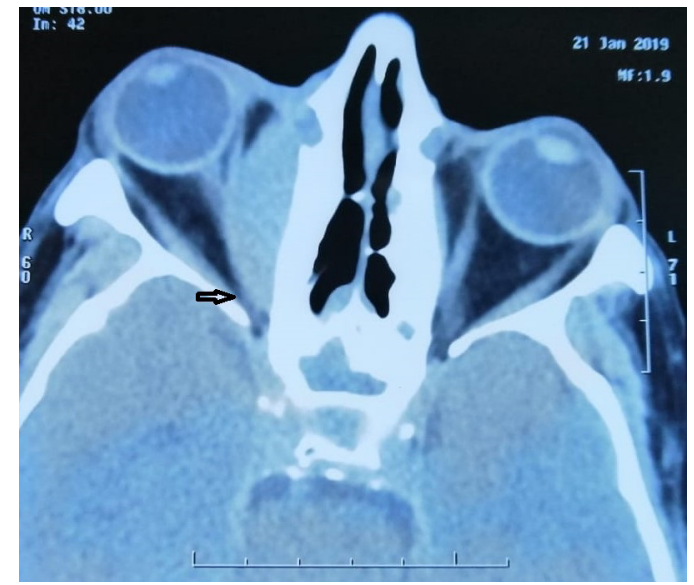

Figure 2 CT image of the orbits, axial section showing homogenous soft tissue density occupying extraconal compartment of bilateral orbits more on the right side along lamina papyracea. Crowding of orbital apex can be noted in the right eye (black arrow).

was noted occupying extraconal compartment of bilateral orbits along lamina papyracea and roof of orbits(figure 2). Crowding of orbital apex was noted in the right eye. Findings were suggestive of fibrous dysplasia of bilateral frontal sinuses with mucocele/pyocele extending into the orbits, causing mass effect in the right orbit. He was taken up for frontal mucocele drainage by external approach under general anaesthesia the next day. After the procedure, ocular congestion resolved, intraocular pressure dropped to $14 \mathrm{~mm} \mathrm{Hg}$, anterior chamber depth improved and gonioscopy revealed open angles in all quadrants.

Fibrous dysplasia of the bone is a benign condition in which cavity of the bone is filled with fibrous tissue, which is prone for diffuse thickening and expansion of the bone. ${ }^{1}$ Therefore, it can cause encroachment on adjacent structures. Craniofacial fibrous dysplasia can cause obstruction of osteum of paranasal sinuses, which may result in mucocele formation.

Secondary rise in intraocular pressure can occur in various orbital conditions such as thyroid orbitopathy, intraorbital mass lesions and arteriovenous malformations. ${ }^{2}$ These orbital conditions can give rise to both open angle and angle closure type of glaucoma.

Open angle glaucoma is caused by raised episcleral venous pressure, which results in equal rise in intraocular pressure. These patients may have tortuous episcleral vessels, wide-open anterior chamber angles and blood in schlemm's canal. 


\section{Learning points}

Secondary angle closure glaucoma can occur due to venous outflow obstruction of the orbit.

- Appropriate radiologic investigation and treatment of underlying cause are the keys for successful outcome.

Angle closure glaucoma is relatively rare, and the mechanism appears to be venous stasis within the vortex veins leading to serous choroidal detachment and subsequent forward displacement of lens-iris diaphragm. ${ }^{3}$ Acute angle closure glaucoma in our patient could be due to orbital congestion and venous stasis causing choroidal effusion, which resolved spontaneously after the drainage of the mucocele.
Contributors TMM contributed to manuscript writing and patient care. SS contributed to patient management. GRR and MV made a intellectual contribution and edited the manuscript.

Funding The authors have not declared a specific grant for this research from any funding agency in the public, commercial or not-for-profit sectors.

Competing interests None declared.

Patient consent for publication Obtained.

Provenance and peer review Not commissioned; externally peer reviewed.

\section{REFERENCES}

1 Liakos GM, Walker CB, Carruth JA. Ocular complications in craniofacial fibrous dysplasia. Br J Ophthalmol 1979;63:611-6.

2 Nassr MA, Morris CL, Netland PA, et al. Intraocular pressure change in orbital disease. Surv Ophthalmol 2009;54:519-44.

3 Zborowski-Gutman L, Gutman I, Chen V, et al. Acute angle closure glaucoma precipitated by orbital pseudotumour. Br J Ophthalmol 1988;72:142-4.

Copyright 2019 BMJ Publishing Group. All rights reserved. For permission to reuse any of this content visit

https://www.bmj.com/company/products-services/rights-and-licensing/permissions/

BMJ Case Report Fellows may re-use this article for personal use and teaching without any further permission.

Become a Fellow of BMJ Case Reports today and you can:

- Submit as many cases as you like

- Enjoy fast sympathetic peer review and rapid publication of accepted articles

- Access all the published articles

- Re-use any of the published material for personal use and teaching without further permission

\section{Customer Service}

If you have any further queries about your subscription, please contact our customer services team on +44 (0) 2071111105 or via email at support@bmj.com.

Visit casereports.bmj.com for more articles like this and to become a Fellow 